Субтропическое и декоративное садоводство (74)

8. Сиденко Т.И., Митрофанова И.В. Особенности введения в культуру in vitro некоторых сортов садовой группы миниатюрных роз // Бюллетень Государственного Никитского ботанического сада. - 2011. - № 133. - С. 41-53. - ISSN 0513-1634.

9. Modern Roses XI. The World Encyclopedia of Roses. - Academic Press, 2000.

10. Murashige T., Skoog F. A revised medium for rapid growth and bioassays with tobacco tissue cultures // Phsiol. plant. - 1962. - Vol. 15. - № 3. - P. 473-497.

\title{
SPECIFICS OF CLONAL MICROPROPAGATION OF MINIATURE (MIN) AND HYBRID TEA (HT \& CL HT) ROSE CULTIVAR GROUPS
}

\author{
Malayeva Ye. V. ${ }^{1,2}$ \\ ${ }^{1}$ State Budgetary Institution of Volgograd region \\ "Volgograd Regional Botanical Garden" \\ ${ }^{2}$ Volgograd State Social \& Pedagogical University \\ Volgograd,Russia,e.malaeva@mail.ru
}

The work is devoted to improvement of clonal micropropagation techniques for valuable rose cultivars - miniature (Min) and hybrid tea (HT \& Cl HT). The specifics of morphogenetic processes are studied and the conditions of in vitro cultivation at all stages are optimized. The influence of various growth regulators on the growth and development of plant regenerants in vitro was determined. The highest multiplication factor of the majority of studied cultivars was obtained by culturing on culture media containing $0,5 \mathrm{mg} / 1$ 6-BAP. The optimum medium for microshoots rooting was MS with $0,5 \mathrm{mg} / 1 \mathrm{IAA}$.

Key words: clonal micropropagation, coefficient of reproduction, growth regulators, rhizogenesis, in vitro, Rosa L.

УДК 581.1

doi: 10.31360/2225-3068-2020-74-92-99

\section{ТРАНСГЕННЫЕ РАСТЕНИЯ: ФУНДАМЕНТАЛЬНОЕ И ПРАКТИЧЕСКОЕ ПРИМЕНЕНИЕ}

Цыпурская Е. В., Загоскина Н. В.

\author{
Институт физиологии растений \\ им. К.А. Тимирязева Российской академии наук, \\ 2. Москва, Россия, e-mail: elena-pr22@mail.ru
}

Трансгенные растения, полученные с использованием методов генной инженерии, представляют собой уникальные биотехнологические объекты для фундаментального и практического применения. В различных лабораториях мира создают трансгенные культуры с генами, связанными с устойчивостью к насекомым, вирусам, грибным и бактериальным патогенам, гербицидам и 
Глава 4. Биотехнология растений

абиотическим стрессам, повышением питательности и качества урожая, а также синтезом белков медицинского назначения. Рассмотрены основные направления исследований в области их получения. Уделено внимание устойчивости трансгенных растений к действию различных стрессовых факторов. Сообщается о десатуразах, важная роль которым отводится в формировании и функционировании биологических мембран, а также их значении. Приводятся примеры растений, трансформированных генами десатураз, и их устойчивости к температурным стрессорам.

Ключевые слова: растения, трансформация, десатуразы, устойчивость к температурам.

К одним из интенсивно развивающихся биотехнологических направлений в области биологии относится использование методов генной инженерии, в том числе для получения различных видов трансгенных растений [18]. Для этих целей используется генетическая информация вирусов, бактерий, насекомых, животных и человека. Трансгенные растения широко используются как для изучения функций отдельных генов, так и для реконструкции сетей взаимодействующих генов, контролирующих формирование морфологических, биохимических и физиологических признаков в процессе развития и при воздействии внешних факторов различной природы [8]. В настоящее время методами генной инженерии получены новые сорта растений с улучшенными вкусовыми качествами, толерантностью к заболеваниям, резистентностью по отношению к вредителям, холоду, засухе и другим воздействиям [11]. Следует также отметить, что трансгенные растения - прекрасный симбиоз фундаментальных и практических задач. С одной стороны, исследователям удаётся изучить изменения в метаболизме растительных клеток при введении в них «нужных» генов, с другой - создать экономически ценные культуры $[32,34]$.

Первые линии трансгенных растений были получены сорок лет назад с помощью векторной системы, основанной на Agrobacterium tumefaciens $[19,24]$. За минувшие десятилетия технологии их создания стали общепринятым способом исследования функций отдельных генов и их систем. Получение трансгенных растений требует разработки схемы генетической конструкции, зависящей от вида и генотипа растения, а также способа трансформации. Например, культурные растения чаще всего трансформируют путём прямой регенерации побегов или соматического эмбриогенеза с использованием агробактерий или биобаллистики [22]. После проведения агробактериальной трансформации растительные клетки культивируют в условиях in vitro 
на питательных средах с добавлением селективных агентов. В дальнейшем устойчивые клетки помещают на среды для регенерации трансформантов и после восстановления полноценных растений подтверждают событие интеграции трансгена с помощью молекулярных методов (ПЦР, Саузерн-блот) [6]. Такой подход - не единственная процедура получения генетически трансформированных растений, но её можно отнести к классическим способам, наиболее часто используемым в условиях in vitro.

Следует отметить работы по введению генов высокомолекулярных глютенинов (1Dx5, 1Ax1, 1Bx17, 1By18, 1Dy10 и др.) в геномы различных линий и сортов мягкой пшеницы. Это позволило получить её трансгенные линии с улучшенным качеством муки, повышенной подъёмной силой теста и его эластичностью [20]. Еще одно важное направление - устранение дефицита витамина А у населения развивающихся стран мира за счёт создания культур с повышенным содержанием каротиноидов [33]. Кроме того, трансгенные технологии позволяют в широких пределах сочетать в одном организме полезные гены различных организмов, тем самым преодолевая не только межвидовые, но и природные репродуктивные барьеры. Показано соединение генов глубоководных рыб и томатов (для придания последним морозостойкости), скорпиона и картофеля (для борьбы с колорадским жуком), кукурузы и бактерии (для выработки инсектицидного токсина у кукурузы), свиньи и шпината (для получения ненасыщенных жирных кислот в сале взамен насыщенных) [36; 40]. Такого «смешивания» генов природа не допускает, в отличие от генной инженерии. Все это свидетельствует о том, что трансгенные технологии - это могущественный инструмент, позволяющий расширить возможности традиционных скрещиваний и селекционных методов [33].

Известно, что в естественных условиях произрастания растения испытывают действие неблагоприятных факторов биотической и абиотической природы, что требует перестройки их метаболизма для сохранения жизнедеятельности $[2,17]$. Это касается и оптимального температурного диапазона, который в России подвержен значительным изменениям (от высоких к низким положительным и отрицательным температурам), представляющим серьёзную угрозу для их роста и развития $[14,21,28]$. Это касается и различных субтропических культур, в частности растений чая, которые в летний период сталкиваются с засухой, приводящей к окислительному стрессу и формированию минеральной недостаточности. Эти абиотические факторы становятся одной из основных причин снижения урожайности чайных плантаций и даже частичной гибели растений [13]. 
Глава 4. Биотехнология растений

Низкотемпературный стресс часто приводит к замедлению роста растений, а также увяданию, хлорозу или некрозу листьев $[5,35]$. В начальный период его действия происходит значительное снижение устьичной проводимости в листьях, содержания $\mathrm{CO}_{2}$ в межклетниках и интенсивности фотодыхания $[4,15]$. Сообщалось об изменениях в составе липидов клеточных мембран [27], содержании белка и активности ферментов $[35,38]$, перераспределении ионов кальция в клетках [37]. В условиях низкотемпературного стресса ультраструктура клеток, включая пластиды (хлоропласты), митохондрии и другие органеллы растений, отличалась от таковых контрольных вариантов [1, 42].

Первичным барьером на пути действия практически любого стрессфактора являются биологические мембраны растений [20, 21]. Считают, что нарушения в их структуре, когда они переходят из жидкокристаллического состояния в твердое, например, в условиях гипотермии, приводит к повреждению растений [9]. И в этом случае одним из важных факторов адаптации высших растений к условиям низкотемпературного стресса является повышение уровня ненасыщенных жирных кислот [14]. Было показано, что у различающихся по холодоустойчивости видов злаков реализуются разные пути мембранной адаптации к низким температурам, что проявляется различиями в изменении относительного содержания линолевой и $\alpha$ линоленовой кислот [12].

Важная роль в формировании и функционировании биологических мембран отводится ферментам, а именно десатуразам [10]. Этим ферментам свойственна специфичность по отношению к длине углеродной цепи и к месту возникновения двойной связи. Так, например, $\Delta 9$-ациллипидная десатураза (FAD2) формирует первую двойную связь в молекулах жирных кислот, тогда как $\Delta 12$-ацил-липидная десатураза (FAB2) - вторую $[23,30]$. Все это изменяет свойства мембран и, как следствие, физиологические реакции клеток и тканей, включая устойчивость к абиотическим стрессам $[20,21]$. Например, высокое содержание ненасыщенных жирнокислотных остатков в структуре общих липидов мембран способствует повышенной устойчивости многолетнего дикорастущего злака пырейника сибирского к низким температурам [12].

Были также проведены исследования по изучению генетически модифицированных генами десатураз растений и их устойчивости к стрессовым воздействиям [26, 31]. Экспрессия гена цианобактериальной $\Delta 12$-ациллипидной десатуразы повышала устойчивость растений картофеля к гипотермии и поражению фитофторой $[7,16]$. Сообщалось о создании трансгенных томатов с повышенной экспрессией гена LeFAD3 $\omega 3$-десатуразы, локализованной в ЭПР растений [39]. Для трансформантов характерно 
улучшение ростовых характеристик в условиях солевого стресса по сравнению с нетрансформированными растениями, а при повышении экспрессии того же самого гена - улучшалась их выживаемость и при низких температурах за счёт повышения содержания линоленовой кислоты.

В настоящее время доказана взаимосвязь между изменением температуры окружающей среды, концентрации осмотических веществ и солей, а также экспрессии некоторых генов десатураз у высших растений [3]. В большинстве случаев в ответ на воздействие низких температур их экспрессия увеличивалась $[25,29]$, тогда как при повышении температуры отмечена обратная реакция [42]. У люцерны Medicago truncatula под действием низких температур экспрессия генов FAD3 и FAD7 (кодируют 03 -десатуразы, локализованы в ЭПР и хлоропластах соответственно) значительно увеличивается по сравнению с растениями, выращенными в нормальных условиях. На основании этих результатов высказано предположение, что эти десатуразы могут играть ключевую роль в реакции растений на низкотемпературный стресс [42]. Аналогичные результаты получены при исследовании генов десатураз хлопчатника. Ген FAD7/8-1, локализованный в хлоропластах и кодирующий $\omega 3$-десатуразу, имел повышенный уровень экспрессии в ответ на низкие температуры и на засуху [41].

Следует отметить большой интерес исследователей к изучению действия десатураз, их роли в растениях, а также изменении свойств растений-трансформантов [3, 10]. Показано их участие в функционировании мембран, регуляции устойчивости растений, в том числе воздействию различных температур. Все это служит основой для изучения «вклада» десатураз в адаптацию субтропических культур.

\section{Библиографический список}

1. Астахова Н.В., Дёмин И.Н., Нарайкина Н.В., Трунова Т.И. Влияние гена desA $\Delta 12$-ациллипидной десатуразы на структуру хлоропластов и устойчивость к гипотермии растений картофеля // Физиология растений. - 2011. - Т. 58. - № 1. - С. 21-27. - ISSN 0015-3303.

2. Белоус О.Г., Маляровская В.И. Оценка адаптивности красивоцветущих растений к стресс-факторам субтропиков России // Бюллетень государственного Никитского ботанического сада. - 2016. - № 121. - С. 39-47. - ISSN 0513-1634.

3. Берестовой М.А., Павленко О.С., Голденкова-Павлова И.В. Десатуразы жирных кислот растений: роль в жизнедеятельности растений и биотехнологический потенциал // Успехи современной биологии. - 2019. - Т. 139. - № 4. - С. 338-351. - ISSN 0042-1324.

4. Венжик Ю.В., Титов А.Ф., Таланова В.В., Фролова С.А., Таланов А.В., Назаркина Е.А. Влияние пониженной температуры на устойчивость и функциональную активность фотосинтетического аппарата растений пшеницы // Известия Российской академии наук. Серия биологическая. - 2011. - № 2. - С. 171-177. - ISSN 1026-3470.

5. Веселов Д.С., Кудоярова Г.Р., Кудрякова Н.В., Кузнецов В.В. Роль цитокининов в стресс-устойчивости растений // Физиология растений. - 2017. - Т. 64. - № 1. - 
C. 19-32. - ISSN 0015-3303.

6. Дейнеко Е.В. Генетическая инженерия растений // Вавиловский журнал генетики и селекции. - 2015. - Т. 18. - № 1. - С. 125-137. - ISSN 2500-0462.

7. Демин И.Н., Дерябин А.Н., Синькевич М.С., Трунова Т.И. Введение гена desA $\Delta 12$-ацил-липидной десатуразы цианобактерии повышает устойчивость растений картофеля к окислительному стрессу, вызванному гипотермией // Физиология растений. - 2008. -Т. 55. - С. 710-720. - ISSN 0015-3303.

8. Кочетов А.В., Шумный В.К. Трансгенные растения как генетические модели для изучения функций генов растений // Вавиловский журнал генетики и селекции. 2016. - T. 20(4). - C. 475-481. - ISSN 2500-0462.

9. Креславский В.Д., Лось Д.А., Аллахвердиев С.И., Кузнецов В.В. Сигнальная роль активных форм кислорода при стрессе у растений // Физиология растений. - 2012. T. 59(2). - С. 163-163. - ISSN 0015-3303.

10. Лось Д.А. Десатуразы жирных кислот. - М.: Научный мир, 2014. - С. 372. - ISBN 978-5-91522.

11. Лутова Л.А. Биотехнология высших растений. - Санкт-Петербург: СПбГУ, 2010. 240 c. - ISBN 978-5-288-05048-0.

12. Макаренко С.П., Дударева Л.В., Катышев А.И., Коненкина Т.А., Назарова А.В., Рудиковская Е.Г., Константинов Ю.М. Влияние низких температур на жирнокислотный состав контрастных по холодоустойчивости видов злаков // Биологические мембраны: Журнал мембранной и клеточной биологии. - 2010. - Т. 27(6). - С. 482-488. - ISSN 0233-4755.

13. Самарина Л.С. Рындин А.В., Малюкова Л.С., Гвасалия М.В., Маляровская В.И. Физиологические и генетические механизмы ответа Camellia sinensis (L.) Kuntze на засуху // Сельскохозяйственная биология. - 2019. - Т. 54. - № 3. - С. 458-468. - ISSN 0131-6397.

14. Трунова Т.И. Растение и низкотемпературный стресс. Тимирязевские чтения. М.: Наука, 2007. - Т. 64. - 54 с.

15. Холонцева Е.С., Таланова В.В. Влияние низкой температуры и кадмия на интенсивность фотодыхания проростков пшеницы // Труды Карельского научного центра Российской академии наук. - 2018. - № 6. - С. 22-29. - ISSN 1997-3217.

16. Юрьева Н.О., Кукушкина Л.Н., Пчёлкин В.П., Соболькова Г.И., Никифорова Х.Р., Голденкова Павлова И.В., Носов А.М., Цыдендамбаев В.Д. Экспрессия гена $\Delta 12$ ацил- липидной десатуразы Synechocystis sp. PCC 6803 повышает устойчивость растений картофеля к поражению фитофторой // Физиология растений. - 2014. - Т. 61. - № 5. - C. 713-720. - ISSN 0015-3303.

17. Яруллина Л.Г., Ибрагимов Р.И. Клеточные механизмы формирования устойчивости растений к грибным патогенам. - 2006. - 228 с. - ISBN 5-7501-0745-0

18. Allred J. Transgenic plants // Research Handbook on Intellectual Property and the Life Sciences. Eds. Matthews D., Zech H. Edward Elgar Publishing. - 2017. - P. 179196. - doi.: 10.4337/9781783479450.00018.

19. Bevan M.W., Flavell R.B., Chilton M.D. A chimaeric antibiotic resistance gene as a selectable marker for plant cell transformation // Nature. - 1983. - Vol. 304. - № 5922. P. 184-187. - doi: 10.1038/304184a0.

20. Blech A., Lin J., Nguyen S., Chan R., Anderson O.D., Dupont F.M. Transgenic wheats with elevated levels of Dx5 and or Dy 10 high-molecular-weight glutenin subunits yield doughs with increased mixing strength and tolerance // J. Cereal Sci. 2007. - Vol. 45. - № 1. - P. 172-183. - doi: 10.1016/j.jcs.2006.07.009

21. Blum A. Plant breeding for stress environments. - Boca Ration: CRC Press. -2018. -231 p. 
22. Brand M. H. Ornamental plant transformation // Journal of Crop Improvement. - 2006. - Vol. 17. - № 1-2. - P. 27-50. - doi.: 10.1300/J411v17n01_02.

23. Chi X., Yang Q., Pan L., Chen M., He Y., Yang Z., Yu S. Isolation and characterization of fatty acid desaturase genes from peanut (Arachis hypogaea L.) // Plant cell reports. 2011. - Vol. 30. - № 8. - P. 1393-1404. - doi: 10.1007/s00299-011-1048-4.

24. Chilton M.D., De Framond A., Byrne M., Fraley R., Chilton W.S., Fenning L., Koplow J. T-DNA of the Agrobacterium Ti and Ri plasmids as vectors // Structure and function of plant genomes. - Springer, Boston, MA., 1983. - P. 409-418. - doi.: 10.1007/978-1-4684-4538-1_39. 25. Feng J., Dong Y., Liu W., He Q., Daud M.K., Chen J., Zhu S. Genome-wide identification of membrane-bound fatty acid desaturase genes in Gossypium hirsutum and their expressions during abiotic stress // Sci. Rep. - 2017. - Vol. 7. - P. 11-12.

26. Gerasymenko I.M., Sakhno L.A., Kyrpa T.N., Ostapchuk A.M., Hadjiev T.A., Goldenova-Pavlova I.V., Sheludko Y.V. Characterization of Nicotiana tabacum plants expressing hybrid genes of cyanobacterial $\Delta 9$ or $\Delta 12$ acyl-lipid desaturases and thermostable lichenase // Russian Journal of Plant Physiology. - 2015. - Vol. 62. - № 3. - P. 283-291. - doi: 10.1134/S1021443715030073.

27. Huner M., Krol J.P., Williams E., Malssan Z. Krupa. Development at Cold-Hardening Temperatures: Membrane Assembly and Organization // Low Temperature Stress Physiology in Crops / Eds. Li P. H., CRC Press. - 2018. - P. 53-67

28. Karakurt Y., Huber D.J. Activities of several membrane and cell-wall hydrolases, ethylene biosynthetic enzymes, and cell wall polyuronide degradation during low-temperature storage of intact and fresh-cut papaya (Carica papaya) fruit // Postharvest Biology and Technology. - 2003. - Vol. 28. - № 2. - P. 219-229. - doi: 10.1016/S0925-5214(02)00177-1.

29. Liu W., Li W., He Q., Daud M.K., Chen J., Zhu S. Characterization of 19 genes encoding membrane-bound fatty acid desaturases and their expression profiles in Gossypium raimondii under low temperature // PLoS One. - 2015. - Vol. 10. - № 4. - P. e0123281. - ISSN 1932-6203. 30. Los D.A., Mironov K.S., Allakhverdiev S.I. Regulatory role of membrane fluidity in gene expression and physiological functions // Photosynthesis research. - 2013. - Vol. 116. - № 2-3. - P. 489-509. - doi: 10.1007/s11120-013-9823-4.

31. Madi L., Wang X., Kobiler I., Lichter A., Prusky D.L. Stress on avocado fruits regulates $\triangle 9$-stearoyl ACP desaturase expression, fatty acid composition, antifungal diene level and resistance to Colletotrichum gloeosporioides attack // Physiological and molecular plant pathology. - 2003. - Vol. 62. - № 5. - P. 277-283. - doi: 10.1016/S0885-5765(03)00076-6. 32. Orbović V., Fields J.S., Syvertsen J.P. Transgenic citrus plants expressing the p35 antiapoptotic gene have altered response to abiotic stress // Horticulture, Environment, and Biotechnology. - 2017. - Vol. 58. - № 3. - P. 303-309. - doi: 10.1007/s13580-017-0196-z. 33. Parmar N. Singh K.H., Sharma D., Singh L., Kumar P., Nanjundan J., Thakur A.K. Genetic engineering strategies for biotic and abiotic stress tolerance and quality enhancement in horticultural crops: a comprehensive review // 3 Biotech. - 2017. - Vol. 7. - № 4. - P. 239. - doi: 10.1007/s13205-017-0870-y.

34. Pike S., Gassmann W., Su J. Generating transgenic arabidopsis plants for functional analysis of pathogen effectors and corresponding $\mathrm{r}$ proteins // Plant Innate Immunity. - Humana, New York, NY. - 2019. - P. 199-206. - doi: 10.1007/978-1-4939-9458-8_18.

35. Ruelland E., Zachowski A. How plants sense temperature // Environmental and Experimental Botany. - 2010. - Vol. 69. - № 3. - P. 225-232. - doi.: 10.1016/j.envexpbot.2010.05.011.

36. Saeki K., Matsumoto K., Kinoshita M., Suzuki I., Tasaka Y., Kano K., Hosoi Y. L. Functional expression of a $\Delta 12$ fatty acid desaturase gene from spinach in transgenic pigs // Proceedings of the National Academy of Sciences. - 2004. - Vol. 101. - № 17. - C. 6361- 
6366. - doi: 10.1073/pnas.0308111101.

37. Seo P.J., Kim M.J., Park J.Y., Kim S.Y., Jeon J., Lee Y.H., Park C.M. Cold activation of a plasma membrane-tethered NAC transcription factor induces a pathogen resistance response in Arabidopsis // The Plant Journal. - 2010. - T. 61. - № 4. - C. 661-671. doi: 10.1111/j.1365-313X.2009.04091.x.

38. Szymańska R., Ślesak I, Orzechowska A., Kruk J. Physiological and biochemical responses to high light and temperature stress in plants // Environmental and Experimental Botany. - 2017. - Vol. 139. - P. 165-177. - doi: 10.1016/j.envexpbot.2017.05.002.

39. Wang H.S. A tomato endoplasmic reticulum (ER)-type omega-3 fatty acid desaturase (LeFAD3) functions in early seedling tolerance to salinity stress // Plant Cell Rep. - 2014. - Vol. 1(33). - P. 131-142. - ISSN 0721-7714.

40. Wang J., Chen Z., Du J., Sun Y., Liang A.1. Novel insect resistance in Brassica napus developed by transformation of chitinase and scorpion toxin genes // Plant Cell Rep. - 2005. - Vol. 24. - № 9. - P. 549-555. - doi: 10.1007/s00299-005-0967-3.

41. Yurchenko O., Park S., Ilut D.C., Inmon J.J., Millhollon J.C., Liechty Z., Gore M.A. Genome-wide analysis of the omega-3 fatty acid desaturase gene family in Gossypium // BMC Plant Biol. - 2014. - Vol. 14. - № 1. - P. 312. - doi: 10.1186/s12870-014-0312-5.

42. Zhang H., Shi Y., Liu X., Wang R., Li J., Xu J. Transgenic creeping bentgrass plants expressing a Picea wilsonii dehydrin gene (PicW) demonstrate improved freezing tolerance // Molecular biology reports. - 2018. - Vol. 45. - № 6. - P. 1627 1635. - doi: 10.1007/s11033-018-4304-7.

43. Zhang, Z., Wei, X., Liu W., Min X., Jin X., Ndayambaza B., Wang Y. Genome-wide identification and expression analysis of the fatty acid desaturase genes in Medicago truncatula // Biochem. Biophys. Res. Commun. - 2018. - Vol. 499. - № 2. - P. 361-367. doi: 10.1016/j.bbrc.2018.03.165.

\title{
TRANSGENIC PLANTS: FUNDAMENTAL AND PRACTICAL APPLICATION
}

Tsypurskaya Ye. V., Zagoskina N. V.

\author{
K. A. Timiryazev Institute of Plants Physiology \\ of the Russian Academy of Sciences, \\ Moscow, Russia,e-mail:elena-pr22@mail.ru
}

Transgenic plants obtained using genetic engineering methods are unique biotechnological objects for fundamental and practical applications. In various laboratories around the world, transgenic lines with genes associated with resistance to insects, viruses, fungal and bacterial pathogens, herbicides and abiotic stresses, increasing the nutritional value and quality of crops, as well as the synthesis of proteins for medical purposes are being created. The main directions of research in the field of their obtaining are considered. Attention is paid to the resistance of transgenic plants to the action of various stress factors. Desaturases have been reported, which play an important role in the formation and functioning of biological membranes, as well as their significance. Examples of plants transformed with desaturase genes and their resistance to temperature stressors are given.

Key words: plants, transformation, desaturase, resistance to temperatures. 